\title{
NOTE
}

\section{First record of chytridiomycosis in Bolivia (Rhinella quechua; Anura: Bufonidae)}

\author{
J. Sebastián Barrionuevo ${ }^{1, *}$, Rodrigo Aguayo $^{2}$, Esteban O. Lavilla $^{1}$ \\ ${ }^{1}$ Instituto de Herpetología, Fundación Miguel Lillo, Miguel Lillo 251 (4000) Tucumán, Argentina \\ ${ }^{2}$ Centro de Biodiversidad y Genética, Universidad Mayor de San Simón, Cochabamba, Bolivia
}

\begin{abstract}
The finding of tadpoles of Rhinella quechua (Huayramayu River, Carrasco National Park, Cochabamba, Bolivia) with oral abnormalities caused by Batrachochytrium dendrobatidis constitutes the first record of this fungal infection reported for Bolivian amphibians.
\end{abstract}

KEY WORDS: Chytridiomycosis $\cdot$ Rhinella quechua $\cdot$ Bolivia

Resale or republication not permitted without written consent of the publisher

\section{INTRODUCTION}

Chytridiomycosis is an amphibian emerging disease caused by the fungal pathogen Batrachochytrium dendrobatidis. This mortal disease has been linked to the decline of amphibian species worldwide, especially in Australia and Latin America (Berger et al. 1998, Lips et al. 2006), although there is debate about its epidemiology (Alford et al. 2007, Di Rosa et al. 2007, Pounds et al. 2007). Two hypotheses on emerging diseases have been proposed. The novel pathogen hypothesis states that the pathogen has been dispersed recently, affecting naive populations, while the endemic pathogen hypothesis claims that cofactors raise the virulence of the pathogen already present in the environment (Rachowicz et al. 2005, Skerratt et al. 2007).

Bolivia is ranked among the 10 most diverse countries for amphibians in the world, containing around 258 described species (Reichle 2003, R. Aguayo unpubl. data). Even though no large numbers of amphibian deaths have been reported in the country (Reichle 2006), some amphibian populations have experienced declines (De la Riva 2005). The causes of decline are not clear, leaving chytridiomycosis as a possible cause. Although to date, the disease has not been diagnosed in Bolivia, it has been found infecting amphibians in southern Peru (Seimon et al. 2005, 2006) and northwestern Argentina (Barrionuevo \& Mangione 2006).

Here we report the presence of chytridiomycosis in torrent-dwelling tadpoles of Rhinella quechua, whose population status is listed as vulnerable (IUCN 2006, Reichle 2006).

\section{MATERIALS AND METHODS}

Twelve tadpoles of Rhinella quechua were collected on 10 June 2007 from Huayramayu River, Sehuencas Forest, Carrasco National Park (Cochabamba Department, Bolivia, $17^{\circ} 56^{\prime} \mathrm{S}, 65^{\circ} 29^{\prime} \mathrm{W}$ ) at $2530 \mathrm{~m}$ a.s.l. Tadpoles were identified by rearing some of them to metamorphosis. Specimens were anesthetized and fixed in $10 \%$ neutral buffered formaldehyde, and intact voucher specimens are housed in the collection of the Centro de Biodiversidad y Genética, Cochabamba, Bolivia (CBG 1502). Keratinized mouthparts of 3 tadpoles were excised with a clean, sharp scalpel. Standard histological techniques for light microscopy were applied. The samples were sectioned at $6 \mu \mathrm{m}$, stained with hematoxylin and eosin, and examined at 63 and 100x magnification. We analyzed 48 histological sections of tadpole CBG 1502-1, 18 sections of CBG 1502-2, and 18 sections of CBG 1502-3. To identify chytrids, we followed Berger et al. (1999) and Pessier et al. (1999).

\section{RESULTS}

Of the Rhinella quechua tadpoles, 9 had normal mouthparts (Fig. 1a) and 3 tadpoles showed anomalies in the keratinized mouthparts of the oral disc (Fig. 1b). The anomalies included lost, interrupted, or misshapen toothrows, and lack of pigmentation in the toothrows and upper and lower jaw sheaths (Fig. 1b). One of these tadpoles (CBG 1502-1) was positive for Batrachochytrium dendrobatidis under histological exami- 
nation. Zoosporangia at different stages were evident in the stratum corneum of keratinized oral disc skin. Mature zoosporangia are usually round, ranging from 7.5 to $10 \mu \mathrm{m}$ in diameter, with a thin wall (Fig. 2), and contain rounded basophilic zoospores approximately $1 \mu \mathrm{m}$ in diameter. In some zoosporangia, a discharge tube formed by an evagination of the zoosporangium wall was evident. The empty post-discharge zoosporangia were the most frequently observed stages in the stratum corneum. The zoosporangial morphology matches the descriptions provided in previous works (Berger et al. 1999, Pessier et al. 1999). Hyperkeratosis was not observed in any of the examined specimens. In the other 2 tadpoles (CBG 1502-2 and 1502-3), we failed to identify the chytrid fungus, probably due to the clustered distribution of zoosporangia.

\section{DISCUSSION AND CONCLUSIONS}

This is the first report of chytridiomycosis in Bolivia. Although some amphibian population declines have been reported in this country (De la Riva 2005) and the presence of chytrid fungus was highly suspected (De la Riva et al. 2005) and predicted (Ron 2005), until now, the disease had not been diagnosed in any amphibian in the country.
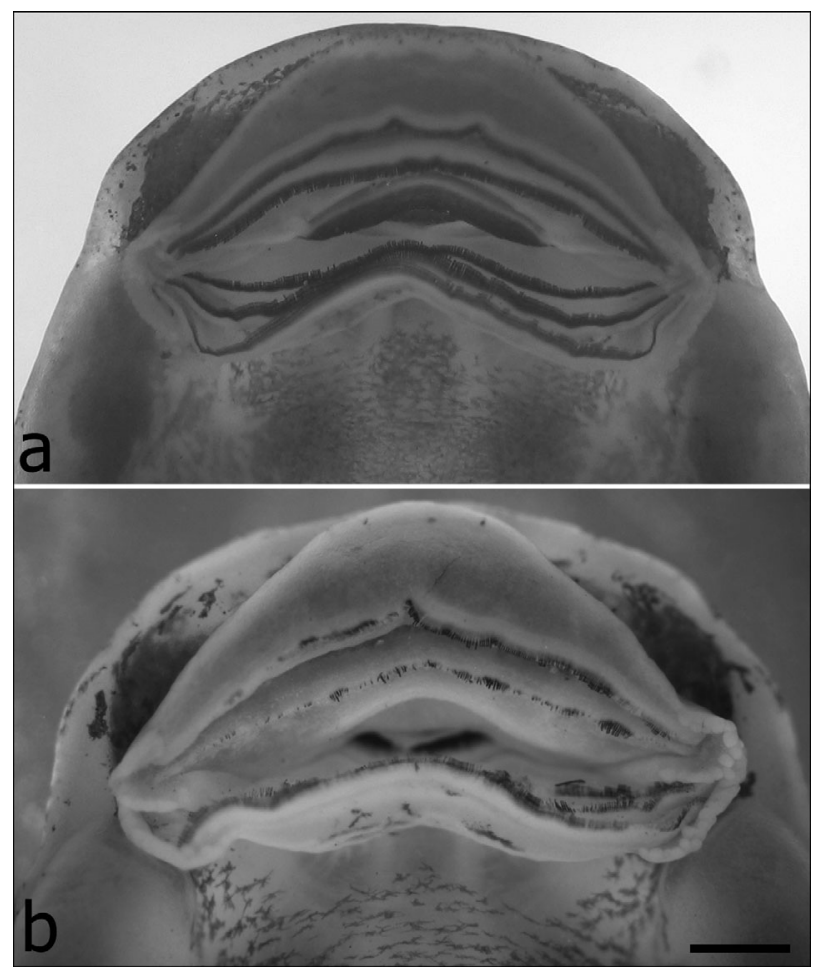

Fig. 1. Rhinella quechua. (a) Normal and (b) abnormal keratinized mouthparts in stage 35 tadpoles (Gosner 1960). $($ Scale bar $=1 \mathrm{~mm})$

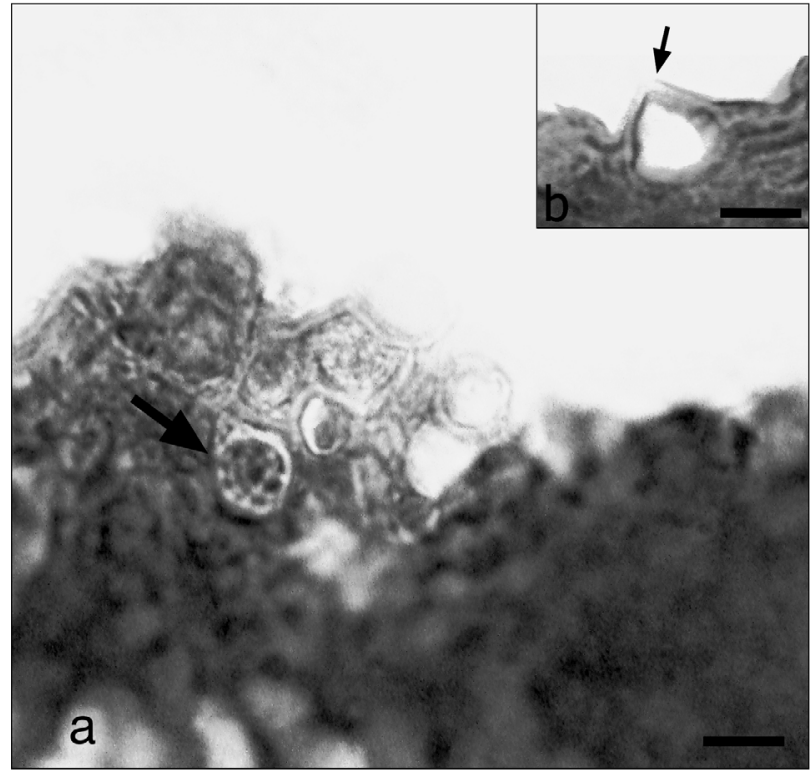

Fig. 2. Rhinella quechua. (a) Skin section of the oral disc of a tadpole. Note mature zoosporangium in the stratum corneum (arrow). Zoospores can be distinguished within the zoosporangia. The rest of zoosporangia are empty (scale bar $=10 \mu \mathrm{m}$ ). (b) An empty zoosporangium with projecting discharge tube (arrow; scale bar $=10 \mu \mathrm{m}$ )

The oral disc anomalies found in tadpoles of Rhinella quechua are coincident with those described as indicative of chytridiomycosis (Fellers et al. 2001, Knapp \& Morgan 2006). Although oral disc anomalies caused by chytridiomycosis differ from those caused by DDT or corticosterone contamination (Fellers et al. 2001) factors other than chytridiomycosis can affect mouthpart pigmentation (e.g. temperature; Rachowicz 2002) or alter toothrow formation (e.g. development, diet; Altig 2007). For these reasons, histological analysis was performed to confirm the presence of chytridiomycosis.

Besides Rhinella quechua, chytridiomycosis has been reported in other closely related new world Bufonidae (R. marina, Daszak et al. 2003; Anaxyrus boreas, Muths et al. 2003; and A. canorus, Green \& Kagarise Sherman 2001). Wild populations of $R$. marina are not declining, even though chytrid fungi can infect and kill individuals (Daszak et al. 2003), but the declines of the 2 species of Anaxyrus in western North America (Carey 1993, Kagarise Sherman \& Morton 1993) were related to the fungus (Green \& Kagarise Sherman 2001, Muths et al. 2003, Carey et al. 2006). The differential effect that Batrachochytrium dendrobatidis has on these species seems to depend on the life history and distribution of the toads (Daszak et al. 2003). While $R$. marina is a lowland, prolific species that has been introduced worldwide, the 2 Anaxyrus 
species are mountain-dwellers and endemic species. $R$. quechua is also a mountain-dweller occurring in humid montane forests (De la Riva et al. 2000), and its presence has been confirmed in only 2 areas of Bolivia (Santa Cruz and Cochabamba).

At present, no field data are available on the population status of Rhinella quechua or its susceptibility to chytridiomycosis, although its habitat and distribution patterns suggest that this species could be negatively affected by chytridiomycosis. In Bolivia, this disease is a potential threat, especially to some species that have been demonstrated to be highly susceptible to chytridiomycosis, like montane aquatic frogs of the genus Telmatobius (Merino-Viteri et al. 2005, Seimon et al. 2005, 2006, Barrionuevo \& Mangione 2006) as well as in other species from the mountain regions of this megadiverse country.

Acknowledgements. We are indebted to Marisa Alcaide and Ana and Franco Pucci, Instituto de Morfología Animal, Fundación Miguel Lillo, for their help in the preparation of histological slides. This project and the collection of samples were supported by a DAPTF seed grant 2006 and a WWF Russell E. Train grant to R.A. for monitoring endangered species in Carrasco National Park, Cochabamba, Bolivia.

\section{LITERATURE CITED}

Alford RA, Bradfield KS, Richards SJ (2007) Global warming and amphibian losses. Nature 447:E3-E4

Altig R (2007) Comments on the descriptions and evaluations of tadpole mouthpart anomalies. Herpetol Conserv Biol 2: $1-4$

Barrionuevo S, Mangione S (2006) Chytridiomycosis in two species of Telmatobius (Anura: Leptodactylidae) from Argentina. Dis Aquat Org 73:171-174

Berger L, Speare R, Daszak P, Green DE and others (1998) Chytridiomycosis causes amphibian mortality associated with population declines in the rain forests of Australia and Central America. Proc Natl Acad Sci USA 95: 9031-9036

Berger L, Speare R, Kent A (1999) Diagnosis of chytridiomycosis in amphibians by histologic examination. www.jcu. edu.au/school/phtm/PHTM/frogs/histo/chhisto.htm

Carey C (1993) Hypothesis concerning the causes of the disappearance of boreal toads from the mountains of Colorado. Conserv Biol 7:355-362

Carey C, Bruzgul JE, Livo LJ, Walling ML and others (2006) Experimental exposures of boreal toads (Bufo boreas) to a pathogenic chytrid fungus (Batrachochytrium dendrobatidis). EcoHealth 3:5-21

Daszak P, Cunningham AA, Hyatt AD (2003) Infectious disease and amphibian population declines. Divers Distrib 9: $141-150$

De la Riva I (2005) Bolivian frogs of the genus Telmatobius (Anura: Leptodactylidae): synopsis, taxonomic comments, and description of a new species. Monogr Herpetol 7 : 65-101

De la Riva I, Köhler J, Lötters S, Reichle S (2000) Ten years of research on Bolivian amphibians: updated checklist, distribution, taxonomic problems, literature and iconography. Rev Esp Herpetol 14:19-164
De la Riva I, Aparicio J, Ríos N (2005) New species of Telmatobius (Anura: Leptodactylidae) from humid paramo of Peru and Bolivia. J Herpetol 39:409-416

> Di Rosa I, Simoncelli F, Fagotti A, Pascolini R (2007) The proximate cause of frog declines? Nature 447:E4-E5

> Fellers GM, Green DE, Longcore JE (2001) Oral chytridiomycosis in the mountain yellow-legged frog (Rana muscosa). Copeia 2001:945-953

Green DE, Kagarise Sherman C (2001) Diagnostic histological findings in Yosemite toads (Bufo canorus) from a die-off in the 1970s. J Herpetol 35:92-103

IUCN, Conservation International, and NatureServe (2006) Global amphibian assessment. www.globalamphibians. org

Kagarise Sherman C, Morton ML (1993) Population declines of Yosemite toads in the eastern Sierra Nevada of California. J Herpetol 27:186-198

Knapp RA, Morgan JAT (2006) Tadpole mouthpart depigmentation as an accurate indicator of chytridiomycosis, an emerging disease of amphibians. Copeia 2006:188-197

- Lips KR, Brem F, Brenes R, Reeve JD and others (2006) Emerging infectious disease and the loss of biodiversity in a neotropical amphibian community. Proc Natl Acad Sci USA 103:3165-3170

Merino-Viteri A, Coloma LA, Almendáriz A (2005) Los Telmatobius (Leptodactylidae) de los Andes del Ecuador y su declive poblacional. Monogr Herpetol 7:9-37

Muths E, Corn PS, Pessier AP, Green DE (2003) Evidence for disease related amphibian decline in Colorado. Biol Conserv 110:357-365

> Pessier AP, Nichols DK, Longcore JE, Fuller MS (1999) Cutaneous chytridiomycosis in poison dart frogs (Dendrobates spp.) and White's tree frogs (Litoria caerulea). J Vet Diagn Investig 11:194-199

Pounds JA, Bustamante MR, Coloma LA, Consuegra JA and others (2007) Global warming and amphibian losses; the proximate cause of frog declines? (Reply). Nature 447:E5E6

Rachowicz LJ (2002) Mouthpart pigmentation in Rana muscosa tadpoles: seasonal changes without chytridiomycosis. Herpetol Rev 33:263-265

Rachowicz LJ, Hero JM, Alford RA, Taylor JW and others (2005) The novel and endemic pathogen hypothesis: competing explanations for the origin of emerging infectious diseases of wildlife. Conserv Biol 19:1441-1448

Reichle S (2003) Anexo 2. Lista de anfibios presentes en Bolivia. In: Ibisch PL, Mérida G (eds) Biodiversidad: la riqueza de Bolivia: estado de conocimiento y conservación. Editorial FAN, Santa Cruz de la Sierra, p 583-585

Reichle S (2006) Distribution, diversity and conservation status of Bolivian amphibians. PhD dissertation, Rheinische Friedrichs-Wilhelm Universität, Bonn

Ron SR (2005) Predicting the distribution of the amphibian pathogen Batrachochytrium dendrobatidis in the New World. Biotropica 37:209-221

Seimon TA, Hoernig G, Sowell P, Halloy S, Seimon A (2005) Identification of chytridiomycosis in Telmatobius marmoratus at $4450 \mathrm{~m}$ in the Cordillera Vilcanota of Southern Peru. Monogr Herpetol 7:273-281

Seimon TA, Seimon A, Daszak P, Halloy SRP, and 6 others (2006) Upward range extension of Andean anurans and chytridiomycosis to extreme elevations in response to tropical deglaciation. Glob Change Biol 13:288-299

Skerratt LF, Berger L, Speare R, Cashins S and others (2007) Spread of chytridiomycosis has caused the rapid global decline and extinction of frogs. EcoHealth 4: 125-134 